T. 2, № 2, 2020

УДК 621.3.052.31

В. Р. Левонюк

Львівський національний аграрний університет, кафедра електротехнічних систем, e-mail: vitaliy_levoniuk@ukr.net

\title{
МАТЕМАТИЧНЕ МОДЕЛЮВАННЯ ПЕРЕХІДНИХ ПРОЦЕСІВ У ТРИФАЗНІЙ ЛІНІЇ ЕЛЕКТРОПЕРЕДАЧІ В РЕЖИМІ ДВОФАЗНОГО КОРОТКОГО ЗАМИКАННЯ
}

https://doi.org/

(С) Левонюк В. Р., 2020

Проаналізовано наукових публікацій, який показав, що здебільшого дослідження перехідних процесів у довгих лініях електропередач з розподіленими параметрами здійснюють шляхом еквівалентації відомого рівняння довгої лінії з розподіленими параметрами коловим еквівалентом або розв'язують це рівняння за допомогою спрощених підходів. Ці підходи потребують детермінованих крайових умов до рівняння довгої лінії, що не завше можливо під час моделювання перехідних процесів в електричних мережах. Також, у багатьох працях автори не враховують у рівняннях стану об'скта погонних активних опору, фазної та міжфазної провідностей, розраховуючи зазвичай згадані процеси за відомим методом Д’Аламбера.

У нинішній праці аналіз перехідних процесів у фрагменті електричної мережі здійснюється на основі модифікованого принципу Гамільтона-Остроградського, що дало змогу отримати вихідні рівняння стану виключно з сдиного енергетичного підходу, ураховуючи тим самим не лише всі перетворення енергії у системі, а й усі розподілені параметри довгої лінії. Так побудовано математичну модель трифазної довгої лінії електропередачі, до якої присднано еквівалентне несиметричне активно-індуктивне навантаження з урахуванням взаємоіндуктивних зв'язків.

Показано, що методика ідентифікації крайових умов другого та третього родів до диференціального рівняння довгої лінії підвищус ефективність побудови їі моделі, оскільки не потребує створення розширених колових заступних схем, 3 одного боку; та дає змогу на польовому рівні врахувати перебіг електромагнітних процесів, з іншого. Для подальшого універсального використання розробленої моделі лінії до неї введено параметр «вихідна напруга».

На підгрунті розробленої математичної моделі здійснено алгоритмізацію та комп'ютерну симуляцію перехідних процесів у лінії електропередачі під час двофазного короткого замикання. Результати досліджень представлено у вигляді рисунків, які аналізуються. Основні представлені у роботі результати отримано з використанням числових методів.

Ключові слова: математичне моделювання, перехідні електромагнітні процеси, принци Гамільтона-Остроградського, довга лінія електропередачі, розподілені параметри, двофазне коротке замикання. 


\section{В. Р. Левонюк}

\section{Постановка проблеми}

Аналіз аварійних режимів в електричних мережах займає чільне місце на етапах проєктування та реалізації електротехнічних систем передачі енергії. Це зумовлено низкою факторів, зокрема порушенням електропостачання споживачів, відмовою систем релейного захисту і автоматики, зниженням якості електричної енергії біля споживачів у післяаварійних режимах, зниженням запасу стійкості енергосистем та ін. Прогнозувати можливість розвитку таких наслідків для адаптування систем електропостачання до аварійних режимів дають змогу розрахувати згадані режими на стадії проєктування досліджуваних систем. Існує багато причин виникнення аварійних режимів. Починаючи з механічних пошкоджень і закінчуючи термодинамічними процесами всередині елементів. Одним 3 дієвих методів аналізу перехідних електромагнітних процесів у фрагментах електричних мереж є залучення апарата математичного моделювання, що, з одного боку не потребує застосування коштовних натурних експериментів, а з іншого - дає змогу отримати результати 3 високим ступенем адекватності.

Сьогодні у світі є потреба у покращанні методів та засобів математичного моделювання процесів та систем. Так, у довідковому виданні [1] Міжнародної ради з великих електричних систем за лютий місяць 2020 року зазначено про необхідність використання досконаліших інструментів та методів моделювання енергосистем, зокрема і перехідних електромагнітних процесів. Особливо актуальним $\epsilon$ застосування моделей, які дають змогу оцінювати досліджувані параметри.

До коли наших інтересів входить зокрема аналіз перехідних процесів у лініях електропередач класу надвисокої напруги. Такі лінії виконують на довжини, що вимірюються сотнями кілометрів, а тому у них хвильові процеси відчутніші, порівняно з лініями інших класів напруг. Тому ці процеси істотно впливають на загальну картину фізичних процесів в електричній мережі. Зазвичай перехідні процеси у лініях електропередач аналізують двояко: за коловими підходами (використання колових заступних схем ліній) або на основі польових підходів. Цілком очевидно, що другий спосіб є на ранг вищим від першого, адже він дає змогу відтворювати перехідні процеси виключно на основі фундаментальних законів прикладної фізики. 3 погляду практичної реалізації польові моделі $є$ значно складніші, оскільки вони описуються не лише звичайними диференціальними рівняннями, а й диференціальними рівняннями з частинними похідними, для розв'язування яких необхідно мати крайові умови. У статті ми розглянемо методику пошуку згаданих крайових умов до диференціального рівняння довгої лінії. 3 одного боку, такий підхід дає змогу розраховувати перехідні процеси 3 високим ступенем адекватності, а $з$ іншого - використовувати модель трифазної лінії електропередачі автономно при моделюванні електричних мереж, у яких присутні маса інших елементів.

\section{Аналіз останніх досліджень}

У науковій літературі $є$ велика кількість робіт, прсвячених аналізу перехідних процесів у довгих лініях електропередач; розглянемо деякі з них, які близькі до нинішньої праці.

У роботі [2] розроблено математичну модель для розрахунку електромагнітних перехідних процесів у трифазних лініях електропередач. Основою розробленої моделі є диференціальні рівняння 3 частинними похідними, які описують електромагнітний стан досліджуваного об’єкта, та крайові і початкові умови. Розроблена математична модель придатна для розрахунку перехідних електромагнітних процесів при аварійних режимах, зокрема, і при двофазних коротких замиканнях.

У статті [3] представлено математичну модель лінії електропередачі, яка грунтується на методах «загублених елементів» та «простору стану лінії». Запропонована методологія являє собою просту та практичну процедуру моделювання трифазної лінії електропередачі безпосередньо у часовій області, без явного використання зворотних перетворень. Також, у моделі лінії враховано частотно-залежні параметри з урахуванням впливу грунту. Крім цього, запропоновано застосовувати процедуру аналітичного інтегрування рівнянь електромагнітного стану, що дає змогу досліджувати перехідні та усталені режими роботи лінії. Представлено задовільну верифікацію отриманих результатів із результатами програмного комплексу $E M T P-R V$. 
У статті [4] представлено математичну модель ідеально транспонованої трифазної лінії електропередачі. Модель дає змогу обчислювати фазні струми та напруги вздовж лінії, як функції часової координати. Рівняння стану записуються відносно струмів та напруг заступної електричної схеми $з$ урахуванням фазних та міжфазних параметрів лінії електропередачі. Тут математичну модель лінії реалізовано у програмному комплексі $E M T P-R V$. Проаналізовано результати комп'ютерної симуляції для увімкнення лінії електропередачі в режимі неробочого ходу.

У роботі [5] описано реалізацію частотної моделі лінії у режимі реального часу. Описано етапи одержання та інтегрування диференціальних рівнянь, які моделюють електромагнітні процеси у багатофазних лініях електропередач з урахуванням параметрів, що залежать від частоти. Модель реалізовано у програмному комплексі MatLab/Simulink, через S-функцію, запрограмовану на мові $C$.

Також варто зазначити праці, перехідні процеси у яких аналізують за допомогою програмного комплексу MatLab з використанням бібліотеки Simulink. Наприклад, у праці [6] здійснено побудову імітаційної моделі трифазної електротехнічної системи пересилання енергії, яка може працювати як у симетричному так, і в несиметричному станах. Тут використано модель лінії, яку вбудовано у згаданій бібліотеці. Такий самий підхід використано і у праці [7]. Тут проаналізовано перехідні процеси при симетричних та асиметричних коротких замиканнях у різних місцях високовольтної лінії електропередачі, яку приєднано до шин генеруючого блоку. Рівняння напруг і струмів лінії електропередачі та шин підстанції записано у фазних координатах, що дає змогу легко моделювати різні асиметричні стани.

Підсумовуючи згадане вище, можемо стверджувати, що математичному моделюванню перехідних процесів у довгих лініях електропередач на польовому рівні приділено недостатньо уваги, натомість моделюванню згаданих процесів за спрощеними підходами, уваги приділено достатньо. Однак, ці підходи потребують чітко заданих крайових умов до рівняння довгої лінії (праці $[2,4]$ ), обтяжені аналітичним інтегруванням (праця [3]). Стосовно програмного комплексу MatLab/Simulink, то тут теж не все так просто, адже модель лінії з розподіленими параметрами, яка вбудована у бібліотеці Simulink, $\epsilon$ спрощеною. У цій моделі не враховано погонних активного опору, фазної та міжфазної провідностей задля спрощення розрахунків за методом Д'Аламбера ([5-7]), що може вплинути на адекватність отриманих результатів.

\section{Формування цілей статті}

Метою роботи $є$ розвиток методів математичного моделювання перехідних електромагнітних процесів у довгих лініях електропередач за нормальних та аварійних режимів роботи.

\section{Виклад основного матеріалу}

Зазвичай для отримання рівнянь електромагнітного стану досліджуваних об'єктів дослідники застосовують два основні підходи: перший - це класичний підхід, який грунтується на законі збереження енергії та другий - варіаційний, що грунтується на мінімізації функціоналу дії досліджуваного об'єкта. Кожен із цих підходів має свої вади та переваги, але за правильного використання вони обидва приводять до вірних результатів [8].

Ми пропонуємо для аналізу перехідних електромагнітних процесів в елементах електричних мереж використовувати модифікований принцип Гамільтона-Остроградського (варіаційний підхід) [9]. Такий підхід дає змогу одержати вихідні рівняння стану виключно з єдиного енергетичного підходу, побудовою розширеної функції Лагранжа. Теорію аналізу перехідних електромагнітних процесів у довгих лініях електропередач на основі варіаційних підходів в однолінійному варіанті розроблено в [9] та розвинено у [10], але для повноцінного відтворення згаданих процесів у довгих лініях електропередач, які часто працюють у несиметричних режимах, їх необхідно моделювати у багатофазному виконанні. Тому ми побудуємо математичну модель лінії у трифазному виконанні.

На рис. 1 зображено розрахункову заступну схему досліджуваного фрагмента електричної мережі, ключовим елементом якої є довга лінія електропередачі, яка представлена у трифазному виконанні, як лінія із розподіленими параметрами. До початку лінії прикладено напругу, а в кінці - до 


\section{В. Р. Левонюк}

неї під’єднано еквівалентне трифазне несиметричне активно-індуктивне навантаження із взаємоіндуктивними зв'язками.

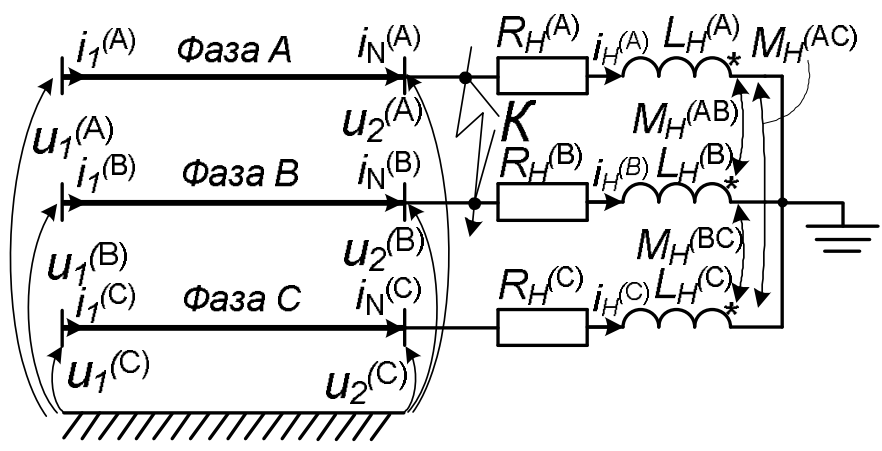

Рис. 1. Розрахункова заступна схема

досліджуваного фрагмента електричної мережі

Оскільки ми розглядаємо об’єкт, який складається з елементів із зосередженими та розподіленими параметрами, розширений функціонал дії за Гамільтоном-Остроградським виглядатиме так [9]:

$$
S=\int_{0}^{t_{1}} L^{*} d t+\int_{0}^{t_{1}} \int_{l} L_{l} d l d t, I=\int_{l} L_{l} d l
$$

де $S$ - дія за Гамільтоном-Остроградським; $L^{*}$ - розширена функція Лагранжа; $L_{l}-$ лінійна густина модифікованої функції Лагранжа; $I$ - енергетичний функціонал.

Розширена функція Лагранжа виглядає так [9]:

$$
L^{*}=\widetilde{T}^{*}-P^{*}+\Phi^{*}-D^{*}, \quad L_{l}=\widetilde{T}_{l}-P_{l}+\Phi_{l}-D_{l},
$$

де $\widetilde{T}^{*}$ - кінетична коенергія; $P^{*}$ - потенціальна енергія; $\Phi^{*}$ - енергія дисипації; $D^{*}$ - енергія сторонніх непотенціальних сил; індекс $l$ позначає густини відповідних енергій (стосується складників розширеної функції Лагранжа для лінії електропередачі, оскільки ії розглядають як систему із розподіленими параметрами).

Ознайомитися з методикою отримання подібних рівнянь електромагнітного стану можна, наприклад, у наших працях $[11,12]$. Тому задля зменшення обсягу матеріалу ми пропонуємо готові рівняння для досліджуваного фрагмента електричної мережі (рис. 1).

Подамо кінцеві рівняння електромагнітного стану досліджуваного фрагмента електричної мережі в матрично-векторному вигляді:

$$
\frac{\partial^{2} \mathbf{u}}{\partial t^{2}}=\left(\mathbf{C}_{0} \mathbf{L}_{0}\right)^{-1}\left(\frac{\partial^{2} \mathbf{u}}{\partial x^{2}}-\left(\mathbf{G}_{0} \mathbf{L}_{0}+\mathbf{C}_{0} \mathbf{R}_{0}\right) \frac{\partial \mathbf{u}}{\partial t}-\mathbf{G}_{0} \mathbf{R}_{0} \mathbf{u}\right), \quad \frac{d}{d t} \mathbf{i}_{H}=\mathbf{L}_{H}^{-1}\left(\mathbf{u}_{2}-\mathbf{R}_{H} \mathbf{i}_{H}\right),
$$

де

$$
\begin{aligned}
& \mathbf{L}_{0}=\begin{array}{|c|c|c|}
\hline L_{0} & M_{0} & M_{0} \\
\hline M_{0} & L_{0} & M_{0} \\
\hline M_{0} & M_{0} & L_{0} \\
\hline
\end{array} \\
& \mathbf{R}_{0}=\begin{array}{|c|c|c|}
\hline R_{0}+R_{Z} & R_{Z} & R_{Z} \\
\hline R_{Z} & R_{0}+R_{Z} & R_{Z} \\
\hline R_{Z} & R_{Z} & R_{0}+R_{Z} \\
\hline
\end{array} \\
& \mathbf{C}_{0}=\begin{array}{|c|c|c|}
\hline C_{0}+2 C & -C & -C \\
\hline-C & C_{0}+2 C & -C \\
\hline-C & -C & C_{0}+2 C \\
\hline
\end{array} ; \\
& \mathbf{G}_{0}=\begin{array}{|c|c|c|}
\hline g_{0}+2 g & -g & -g \\
\hline-g & g_{0}+2 g & -g \\
\hline-g & -g & g_{0}+2 g \\
\hline
\end{array}, \\
& \mathbf{L}_{H}=\begin{array}{|c|c|c|}
\hline L_{H}^{(A)} & M_{H}^{(A B)} & M_{H}^{(A C)} \\
\cline { 2 - 3 } M_{H}^{(B A)} & L_{H}^{(B)} & M_{H}^{(B C)} \\
\cline { 2 - 3 }\left(M_{H}^{(C A)}\right. & M_{H}^{(C B)} & L_{H}^{(C)} \\
\hline
\end{array}
\end{aligned}
$$

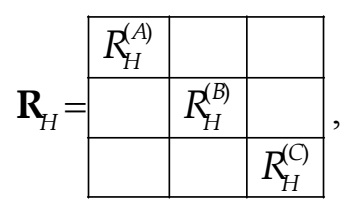

Для ідеально транспонованої лінії у матрицях (4)-(5) $R_{0}, g_{0}, C_{0}, L_{0}$ - погонні опір, провідність, ємність та індуктивність фаз лінії, відповідно; $g, C$ - погонні міжфазні провідність та ємність, 
відповідно; $M_{0}$ - погонна взаємоіндуктивність; $R_{Z}$ - погонний опір землі; $R_{H}{ }^{(k)}, L_{H}{ }^{(k)}$ - опір та індуктивність відповідної фази еквівалентного навантаження; $M_{H}^{(k m)}=M_{H}^{(m k)}-$ взаємоіндуктивність гілок навантаження; $k, m=A, B, C(m \neq \kappa)$ - назва фази.

Проблемою під час розв'язання першого рівняння (3) $\epsilon$ визначення крайових умов. У нашій задачі напруга на початку лінії відома $\left(\mathbf{u}_{1}=\mathbf{u} \mid x=0\right)$, а в кінці лінії - ні. Тому необхідно знайти лише крайову умову в кінці лінії.

У праці [10] для однорідних довгих ліній електропередач (тут розглядалися симетричні режими, тому лінія моделювалася в однофазному (однолінійному) виконанні) нами було запропоновано використовувати для розв'язування рівняння довгої лінії (телеграфного рівняння) крайові умови другого та третього родів (крайові умови Неймана та Пуанкаре), зокрема рівняння, яке можна отримати за другим законом Кірхгофа для електричних кіл із розподіленими параметрами. Пропонуємо використати цей підхід і для трифазних систем. Запишемо згадане рівняння у матрично-векторному вигляді:

$$
-\frac{\partial \mathbf{u}}{\partial x}=\mathbf{R}_{0} \mathbf{i}+\mathbf{L}_{0} \frac{\partial \mathbf{i}}{\partial t}
$$

Дискретизуючи перше рівняння в (3) та рівняння (6) за методом прямих, використовуючи поняття центральної похідної, отримаємо:

$$
\begin{gathered}
\frac{d \mathbf{v}_{j}}{d t}=\left(\mathbf{C}_{0} \mathbf{L}_{0}\right)^{-1}\left(\frac{1}{(\Delta x)^{2}}\left(\mathbf{u}_{j-1}-2 \mathbf{u}_{j}+\mathbf{u}_{j+1}\right)-\left(\mathbf{G}_{0} \mathbf{L}_{0}+\mathbf{C}_{0} \mathbf{R}_{0}\right) \mathbf{v}_{j}-\mathbf{G}_{0} \mathbf{R}_{0} \mathbf{u}_{j}\right), \frac{d \mathbf{u}_{j}}{d t}=\mathbf{v}_{j}, j=2, \ldots, N . \\
\frac{d \mathbf{i}_{j}}{d t}=\mathbf{L}_{0}{ }^{-1} \frac{1}{2 \Delta x}\left(\mathbf{u}_{j-1}-\mathbf{u}_{j+1}\right)-\mathbf{L}_{0}{ }^{-1} \mathbf{R}_{0} \mathbf{i}_{j}, \quad j=2, \ldots, N .
\end{gathered}
$$

Записавши рівняння (7) та (8) для останнього дискретного вузла лінії $(j=N)$, побачимо, що у рівняннях фігуруватиме невідома напруга у вузлі $\mathbf{u}_{N+1}$, що робить неможливим знаходження напруги на останньому дискретному вузлі лінії $\mathbf{u}_{N}$ та струму в останній дискретній гілці лінії $\mathbf{i}_{N}$.

Методику пошуку напруги $\mathbf{u}_{N+1}$ описано та апробовано у праці [10], проте вона не $\epsilon$ досконалою, оскільки для побудови математичних моделей електричних мереж різних конфігурацій з'єднань лінії з іншими елементами вирази, які ії описують, будуть різними, що додатково потребує змін у моделі лінії. Ми ж пропонуємо зробити цю модель лінії більш універсальною уведенням до згаданої моделі параметра «вихідна напруга» (напруга в кінці лінії $\mathbf{u}_{2}=\mathbf{u}_{\mid x=l}\left(\mathbf{u}_{N} \neq\left.\mathbf{u}\right|_{x=l}\right)$, див. рис. 1).

Представимо послідовність знаходження напруги $\mathbf{u}_{N+1}$. Для останнього дискретного контура лінії запишемо рівняння за другим законом Кірхгофа:

$$
\frac{d \mathbf{i}_{N}}{d t}=\left[\Delta x \mathbf{L}_{0}\right]^{-1}\left(\mathbf{u}_{N}-\mathbf{u}_{2}-\Delta x \mathbf{R}_{0} \mathbf{i}_{N}\right) .
$$

Порівнюємо рівняння (8) (записане для останнього дискретного вузла лінії $(j=N)$ ) та рівняння (9)

$$
\mathbf{L}_{0}^{-1} \frac{1}{2 \Delta x}\left(\mathbf{u}_{N-1}-\mathbf{u}_{N+1}\right)-\mathbf{L}_{0}^{-1} \mathbf{R}_{0} \mathbf{i}_{N}=\left[\Delta x \mathbf{L}_{0}\right]^{-1}\left(\mathbf{u}_{N}-\mathbf{u}_{2}-\Delta x \mathbf{R}_{0} \mathbf{i}_{N}\right) .
$$

Визначивши з (10) функцію напруги фіктивного вузла $\mathbf{u}_{N+1}$, отримаємо:

$$
\mathbf{u}_{N+1}=\mathbf{u}_{N-1}+2\left(\mathbf{u}_{2}-\mathbf{u}_{N}\right) \text {. }
$$

Використовуючи вираз (11) як функцію напруги $\mathbf{u}_{N+1}$ можна уникнути ії зміни при зміні конфігурації схеми з'єднання лінії електропередачі з іншими елементами електричної мережі, що робить математичну модель лінії універсальною. Однак, тепер виникла потреба пошуку напруги $\mathbf{u}_{2}$, яка фігурує у формулі (11), і вираз для знаходження якої змінюється із зміною структури схеми, але при цьому не впливає на структуру математичної моделі лінії.

Струм $\mathbf{i}_{N}$ тотожно дорівнює струму $\mathbf{i}_{H}$ (див. рис. 1), отже, з урахуванням початкових умов можемо записати (прирівнюємо похідні струмів): 


$$
\mathbf{i}_{H} \equiv \mathbf{i}_{N} \Rightarrow \frac{d}{d t} \mathbf{i}_{H} \equiv \frac{d}{d t} \mathbf{i}_{N},
$$

звідки, з урахуванням другого рівняння в (3) та рівняння (9), отримаємо:

$$
\mathbf{L}_{H}^{-1}\left(\mathbf{u}_{2}-\mathbf{R}_{H} \mathbf{i}_{N}\right)=\left[\Delta x \mathbf{L}_{0}\right]^{-1}\left(\mathbf{u}_{N}-\mathbf{u}_{2}-\Delta x \mathbf{R}_{0} \mathbf{i}_{N}\right) .
$$

Виразивши за (13) функцію напруги $\mathbf{u}_{2}$, отримаємо:

$$
\mathbf{u}_{2}=\mathbf{L}_{\Sigma}\left(\boldsymbol{\alpha}^{\circ} \mathbf{u}_{N}-\left(\boldsymbol{\alpha}^{\circ} \mathbf{R}^{\circ}-\mathbf{L}_{H} \mathbf{R}_{H}\right) \mathbf{i}_{N}\right)
$$

де

$$
\mathbf{L}_{\Sigma}=\boldsymbol{\alpha}_{\Sigma}{ }^{-1}, \quad \boldsymbol{\alpha}_{\Sigma}=\mathbf{L}_{H}^{-1}+\boldsymbol{\alpha}^{\circ}, \quad \boldsymbol{\alpha}^{\circ}=\left[\Delta x \mathbf{L}_{0}\right]^{-1}, \quad \mathbf{R}^{\circ}=\left[\Delta x \mathbf{R}_{0}\right] .
$$

Значення струму у першій дискретній гілці лінії або ж, за потреби, в усіх дискретних гілках лінії, можна розрахувати дискретизуючи рівняння (6) за методом прямих, але тепер використовуючи поняття правої похідної:

$$
\frac{d \mathbf{i}_{j}}{d t}=\mathbf{L}_{0}^{-1} \frac{1}{\Delta x}\left(\mathbf{u}_{j}-\mathbf{u}_{j+1}\right)-\mathbf{L}_{0}^{-1} \mathbf{R}_{0} \mathbf{i}_{j}, j=1, \ldots, N .
$$

Сумісному інтегруванню підлягає така система диференціальних рівнянь: друге рівняння в (3), (7), (8), (16) з урахуванням (4), (5), (11), (14) та (15).

\section{Результати комп'ютерної симуляції}

Для здійснення комп’ютерної симуляції на основі розробленої математичної моделі алгоритмічною мовою програмування Visual Fortran, нами написали програмний код, який дає змогу відтворювати перехідні електромагнітні процеси у досліджуваному фрагменті електричної мережі (рис. 1). Симуляцію здійснювали для дослідження віддаленого двофазного короткого замикання (міжфазне коротке замикання у кінці лінії електропередачі (точка $K$, див. рис. 1$)$ ).

Симуляцію здійснювали так. У момент часу $t=0$ с вмикали лінію електропередачі 3 несиметричним еквівалентним трифазним активно-індуктивним навантаженням. Після виходу на нормальний усталений режим, у момент часу $t=0,12 \mathrm{c}$, у кінці лінії електропередачі імітувалися двофазне коротке замикання $\mathrm{K}^{(2)}$ (між фазами $A$ та $B$, див. рис. 1 ).

Під час комп'ютерної симуляції ми не враховували роботу протиаварійної автоматики та релейного захисту лінії. Очевидно, що такий варіант не $\epsilon$ цілком реальним, проте симуляція комутаційних процесів під час коротких замикань не є завданням нашої праці.

Для досліджень було прийнято параметри реальної лінії електропередачі 750 кВ, яка з'єднує ПС «Західноукраїнська» (Україна) з ПС «Альбертірша» (Угорщина) довжиною $l=476$ км. Параметри довгої лінії електропередачі, яку прийнято симетричною, такі: $R_{0}=1,9 \cdot 10^{-5} \mathrm{OM} / \mathrm{M}, L_{0}=1,665 \cdot 10^{-6} \Gamma_{\mathrm{H}} / \mathrm{M}$, $C_{0}=1,0131 \cdot 10^{-11} \Phi / \mathrm{M}, g_{0}=3,25 \cdot 10^{-11} \mathrm{CM} / \mathrm{M}, C=1,0122 \cdot 10^{-12} \Phi / \mathrm{M}, g=3,25 \cdot 10^{-13} \mathrm{Cm} / \mathrm{M}, R_{\mathrm{Z}}=5 \cdot 10^{-5} \mathrm{OM} / \mathrm{M}$, $M_{0}=7,41 \cdot 10^{-7} \Gamma /$ м. Параметри еквівалентного трифазного активно-індуктивного навантаження такі: $R_{H}{ }^{(A)}=410$ Ом, $R_{H}{ }^{(B)}=370$ Ом, $R_{H}{ }^{(C)}=390$ Ом, $L_{H}{ }^{(A)}=0,83 \Gamma_{\mathrm{H},} L_{H}{ }^{(B)}=0,68 \Gamma_{\mathrm{H},} L_{H}{ }^{(C)}=0,73$ Гн. Взаємоіндуктивні зв'язки у гілках навантаження (задля спрощення розрахунків) не враховували. Комп'ютерну симуляцію здійснювалися за таких параметрів режиму: $u_{1}^{(A)}=630 \sin (\omega t) \mathrm{\kappa B}, u_{1}^{(B)}=630 \sin (\omega t-$ $\left.120^{\circ}\right)$ кВ, $u_{1}^{(C)}=630 \sin \left(\omega t+120^{\circ}\right)$ кВ. Крок просторової дискретизації диференціальних рівнянь із частинними похідними за методом прямих дорівнює: $\Delta x=l / 20=476 / 20=23,8$ км. Звичайні диференціальні рівняння інтегрувалися числовим методом Гіра із кроком $\Delta t=27$ мкс.

На рис. 2 та 3 представлено фазні струми та напруги по середині лінії, відповідно, де фаза $A-$ жовті лінії, фаза $B$ - зелені, фаза $C$ - червоні.

Аналізуючи одержані часові залежності струмів (рис. 2), бачимо, що після виходу на усталений режим їхні амплітуди дорівнюють 1,33 кА. Після виникнення міжфазного короткого замикання на фазах $A$ та $B\left(t_{\text {Кз }}=0,12\right.$ с) максимальне значення струму фази $A$ становило 4,25 кА, фази $B-$ 9,7 кА, а фази $C-2,5$ кА. Усталений режим короткого замикання настає орієнтовно через 0,15 с 3 амплітудами струмів фази $A 2,85$ кА, фази $B-5$ кА, а фази $C-1,34$ кА. 
Стосовно напруг по середині лінії (рис. 3), то тут в нормальному усталеному режимі амплітудні значення фазних напруг становлять приблизно 620 кВ. Після виникнення двофазного короткого замикання у кінці лінії усталене амплітудне значення напруги фази $B$ зменшилося до 400 кВ, а фаз $A$ та $C$ - зменшилися до 600 кВ.

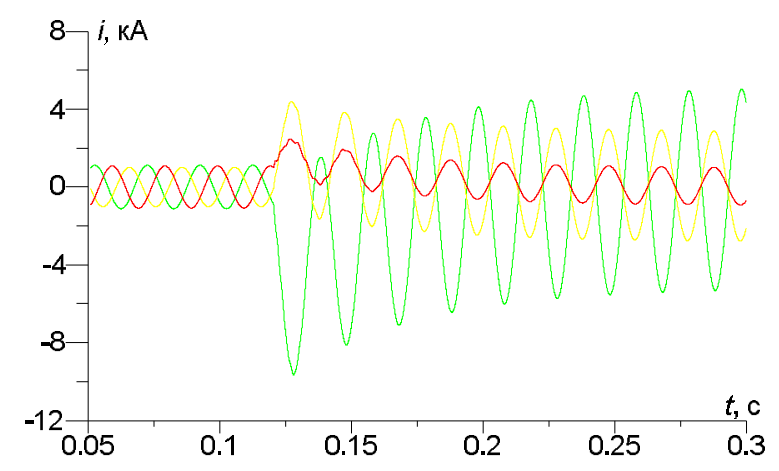

Рис. 2. Перехідні процеси фазних струмів по середині лінії

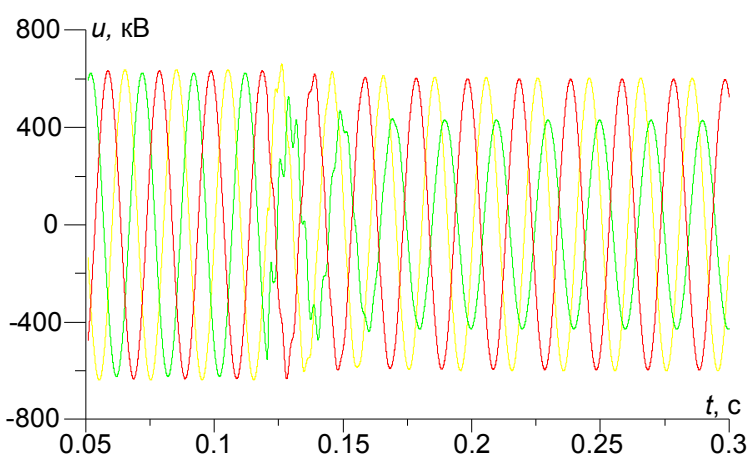

Рис. 3. Перехідні прочеси фазних напруг по середині лінії

На рис. 4 та 5 представлено часово-просторові розподіли напруги та струму фази $B$. Ці рисунки виконано в $3 D$ форматі, вони об'єднують одночасно часовий і просторовий розподіли напруги та струму у лінії.

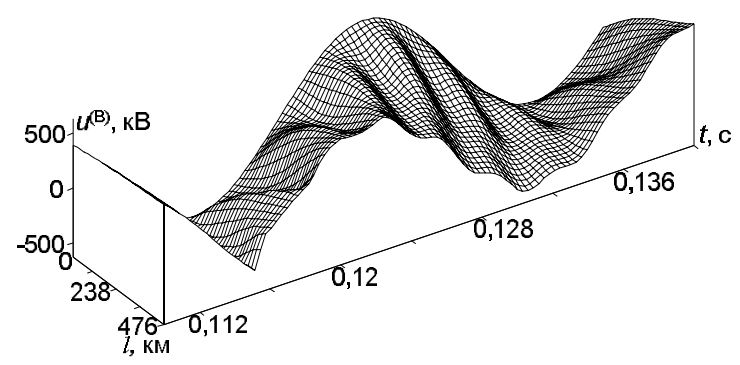

Рис. 4. Часово-просторовий розподіл напруги фази В у лінї у момент часу $t \in[0,11 ; 0,14] \mathrm{c}$

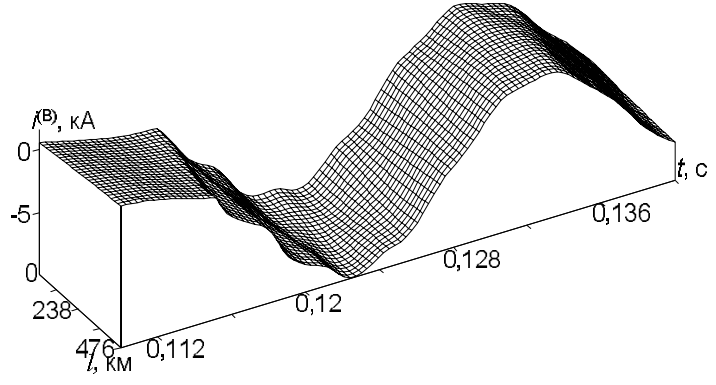

Рис. 5. Часово-просторовий розподіл струму фази В в лінії у момент часу $t \in[0,11 ; 0,14] c$

3 рисунків можемо бачити, як змінюються напруги та струмів у просторі вздовж лінії електропередачі після виникнення короткого замикання для різних моментів часу.

\section{Висновки}

1. Застосування крайових умов Неймана та Пуанкаре як крайових умов до диференціальних рівнянь трифазної довгої лінії дає змогу ефективно розв'язувати задачі, які стосуються аналізу перехідних електромагнітних процесів у лініях надвисокої напруги, де їх необхідно розглядати як системи з розподіленими параметрами.

2. Уведення у математичну модель лінії, яка грунтується на дискретизованому рівнянні довгої лінії, для розв'язання якого застосовано крайові умови другого та третього родів, параметра «вихідна напруга» (напруга в кінці лінії $\mathbf{u}_{2}$ ), дає змогу зробити модель лінії універсальнішою, 3 одного боку, та розкриває ширші можливості для відтворення аварійних режимів лінії-з іншого.

3. Представлені у $3 D$-форматі часово-просторові розподіли напруг та струмів максимально висвітлюють інформацію про хвильові процеси в лінії, що сприятиме грунтовному аналізу аварійних режимів. 


\section{В. Р. Левонюк}

Матеріали цієї роботи буде використано у подальших дослідженнях, які стосуватимуться сумісної роботи турбогенераторів, блочних трансформаторів, комутаційного обладнання та довгих ліній електропередач надвисокої напруги.

\section{Список використаних літературних джерел}

1. https://e-cigre.org/article/cigre-reference-paper--the-need-for-enhanced-power-system-modelling-techniquesand-simulation-tools.

2. Математична модель трифазної лінії з розподіленими параметрами при електромагнітних перехідних прочесах / В. Ю. Лободзинський, В. І. Чибеліс / ВІСНИК КНУТД. - 2018. № 4 (124). С. $96-102$.

3. Efficient procedure to evaluate electromagnetic transients on three-phase transmission lines / E. C. M. Costa, S. Kurokawa, J. Pissolato, A. J. Prado / IET Generation Transmission \& Distribution. - 2010. № 4(9). P. 1069-1081.

4. Model of Three-Phase Transmission Line with the Theory of Modal Decomposition Implied / R. Cleber da Silva, S. Kurokawa / Energy and Power Engineering. - 2013. No 5. P. 1139-1146.

5. Implementation of the Frequency Dependent Line Model (FD-Line) in a Real-Time Power System Simulator / R. Iracheta-Cortez, N. Florez-Guzman, R. Hasimoto-Beltran / Ingenierua e Investigaciyn. - 2017. No 37(3). P. 61-71.

6. MATLAB based Simulations model for three phases Power System Network / C. Vijaya Tharani, M. Nandhini, R. Sundar, K. Nithiyanantha. - International Journal for Research in Applied Science \& Engineering Technology. 2016. Vol. 4. Issue XI. P. 502-509.

7. Analysis of transient waveforms in a power system at asymmetrical short-circuits / P. Pruski, S. Paszek / Przeglad elektrotechniczny. - 2020. Nr 2. S. 26-29.

8. Уайд Д. Електромеханическое преобразование энергии / Д. Уайд, Г. Вудсон. - Л. : Энергия, 1964. - 539 с.

9. Чабан А. В. Принцип Гамільтона-Остроградського в електромеханічних системах / А. В. Чабан. Львів : Вид-во Тараса Сороки, 2015. - 488 с.

10. Левонюк В. Р. Методи та засоби аналізу комутаиійних перехідних прочесів у лініях електропередачі надвисокої напруги на основі варіаційних підходів: дис. ... канд. техн. наук. Львів, 2019. 209 с.

11. Mathematical model of electromagnetic processes in Lehera line at open-circuit operation / A. V. Chaban, V. R. Levoniuk, I. M. Drobot, A. F. Herman / Electrical engineering \& electromechanics. - 2016, No. 3, P. 30-35.

12. Mathematical modelling of transient processes in power systems considering effect of high-voltage circuit breakers / A. Czaban, A. Szafraniec, V. Levoniuk / Przeglad Elektrotechniczny. -2019. No 1. p. 49-52.

\section{References}

1. https://e-cigre.org/article/cigre-reference-paper--the-need-for-enhanced-power-system-modelling-techniques-andsimulation-tools.

2. Lobodzinsky, V. Yu., Chibelis, V. I. (2018). Matematychna model $\square$ tryfaznoyi liniyi z rozpodilenymy parametramy pry elektromahnitnykh perekhidnykh protsesakh [Mathematical model of a three-phase line with distributed parameters in electromagnetic transients]. Bulletin of KNUTD. № 4, P. 96-102.

3. Efficient procedure to evaluate electromagnetic transients on three-phase transmission lines / E. C. M. Costa, S. Kurokawa, J. Pissolato, A. J. Prado / IET Generation Transmission \& Distribution. - 2010. № 4(9). P. $1069-1081$.

4. Model of Three-Phase Transmission Line with the Theory of Modal Decomposition Implied / R. Cleber da Silva, S. Kurokawa / Energy and Power Engineering. - 2013. № 5. P. 1139-1146.

5. Implementation of the Frequency Dependent Line Model (FD-Line) in a Real-Time Power System Simulator / R. Iracheta-Cortez, N. Florez-Guzman, R. Hasimoto-Beltran / Ingenierнa e Investigaciyn. - 2017. № 37(3). P. 61-71.

6. MATLAB based Simulations model for three phases Power System Network / C. Vijaya Tharani, M. Nandhini, R. Sundar, K. Nithiyanantha. - International Journal for Research in Applied Science \& Engineering Technology. - 2016. Vol. 4. Issue XI. P. 502-509.

7. Analysis of transient waveforms in a power system at asymmetrical short-circuits / P. Pruski, S. Paszek / Przeglad elektrotechniczny. -2020. NR 2. S. 26-29.

8. Wide D., Woodson G. (1964). Yelektromekhanicheskoye preobrazovaniye energii [Electromechanical energy conversion]. - Leningrad, 539 p. (rus).

9. Chaban, A. (2015). Pryntsyp Hamiltona-Ostrohradskoho v elektromekhanichnykh systemakh [The principle of Hamilton-Ostrogradsky in electromechanical systems]. - Lviv, 488 p. (ukr).

10. Levoniuk, V. R. (2019). Metody ta zasoby analizu komutatsiynykh perekhidnykh protsesiv u liniyakh 
elektroperedachi nadvysokoyi napruhy na osnovi variatsiynykh pidkhodiv [Methods and means of analysis of switching transients processes in ultra high voltage transmission lines on the basis of variational ap-proaches]. Ph.D. dissertation, Dept. of Electrical Sys-tems, Lviv Nat. Agrarian Univ. Lviv, Ukraine. 209 p.

11. Mathematical model of electromagnetic processes in Lehera line at open-circuit operation / A. V. Chaban, V. R. Levoniuk, I. M. Drobot, A. F. Herman / Electrical engineering \& electromechanics. - 2016, No. 3, P. 30-35.

12. Mathematical modelling of transient processes in power systems considering effect of high-voltage circuit breakers / A. Czaban, A. Szafraniec, V. Levoniuk / Przeglad Elektrotechniczny. -2019. No 1. p. 49-52.

Vitaliy Levoniuk

Lviv National Agrarian University Department of Electrical Systems, e-mail: vitaliy_levoniuk@ukr.net

\author{
MATHEMATICAL MODELING OF TRANSIENTS \\ PROCESSES IN THREE-PHASE TRANSMISSION LINE \\ IN TWO-PHASE SHORT CIRCUIT MODE
}

(C) Levoniuk V., 2020

The article analyzes scientific publications, which showed that for most part of the study transients processes in the long power lines with distributed parameters is carried out by equivalent to the known equation of a long line with distributed parameters by a circular equivalent, or solve this equation using simplified approaches. These approaches require deterministic boundary conditions to the long line equation, which is not always possible when modeling transients processes in electrical networks. Also, in many works the authors do not take into account in the equations of the object linear active resistance, phase and interphase conductivities, calculating the usually mentioned processes by the known method of D'Alembert.

In the present work, the analysis of transients processes in a fragment of the electrical network is based on the modified Hamilton-Ostrogradsky principle, which made it possible to obtain the initial equations of state exclusively from a single energy approach, thus taking into account not only all energy transformations in the system, but also all distributed parameters of the long line. A mathematical model of a long power line is constructed, to which an equivalent asymmetric activeinductive load is connected, taking into account mutual inductive connections.

It is shown that the method of identification boundary conditions of the second and third genera to the differential equation of a long line increases efficiency construction of its model, since it does not require the creation of extended circuit substitution schemes, on the one hand; and makes it possible to take into account the course of electromagnetic processes at the field level, on the other hand. For further universal use of the developed line model, the parameter "output voltage" (voltage at the end of the line) is introduced into it.

Based on the developed mathematical model, algorithmization of dynamic processes and computer simulation of transient modes in the power line during a two-phase short circuit were performed. The research results are presented in the form of figures that are analyzed. All the results presented in this paper were obtained using numerical methods.

Key words: mathematical modeling, transient electromagnetic processes, Hamilton-Ostrogradsky principle, long power line, distributed parameters, two-phase short circuit. 